AGRO EKONOMI, Vol 29, Issue 2, December 2018, Page.346-357

DOI : http://doi.org/10.22146/ae.38696

ISSN 0215-8787 (print), ISSN 2541-1616 (online)

Available at https://jurnal.ugm.ac.id/jae/

\title{
FINANCIAL FEASIBILITY ANALYSIS OF RHIZOSPHERE RESTORATION FOR STEVIA (Stevia Rebausidiana Bertoni M) CULTIVATION AT SUGAR GROUP COMPANIES LAMPUNG
}

\section{Analisis Kelayakan Finansial Perbaikan Rizosfir Untuk Budidaya Stevia (Stevia Rebausidiana Bertoni M) di Sugar Group Companies Lampung}

\author{
Jonathan Jusuf ${ }^{1}$, Azwar Maas $^{2}$, Slamet Hartono ${ }^{2}$ \\ ${ }^{1}$ Master Students of Agricultural Economics, Faculty of Agriculture, \\ Universitas Gadjah Mada \\ ${ }^{2}$ Faculty of Agriculture, Universitas Gadjah Mada \\ Jl. Flora No. 1 Bulaksumur, Yogyakarta \\ jonathan.jusuf@gmail.com
}

Submitted: 29 May 2018; Revised: 3 September 2018; Accepted: 13 November 2018

\begin{abstract}
This research aims to understand the effect of growing media reparation (rhizosphere) on the production of stevia and the financial feasibility of rhizosphere business. The necessary data were retrieved from field research utilizing plot research method along with Complete Randomized Group Design (CRD) comprised of $15 \times 2$ executions and 3 replications. The plot size used was $2 \mathrm{~m} \times 0,6 \mathrm{~m}(1,2 \mathrm{~m} 2)$. Research shows that rhizosphere restoration is able to increase the production of dry stevia leaves.Based on the result, the financial feasibility analysis showing that NPV $>0$ (nol), B/C ratio $>1$, IRR $20 \%$, and both BEP of unit and BEP of price are exceeded indicates that this business is feasible to run. However, it is sensitive on the change of cost and benefit. This study suggests to improve stevia leaves production, higher than the current situation.
\end{abstract}

Keywords: financial feasibility, production, rhizosphere

Jusuf, J., Maas, A., \& Hartono, S .(2018). Financial Feasibility Analysis of Rhizosphere Restoration For Stevia (Stevia Rebausidiana Bertoni M) Cultivation at Sugar Group Companies Lampung. Agro Ekonomi, 29(2) : 346-357

\section{INTISARI}

Tujuan dari penelitian ini adalah (i) menganalisis dampak restorasi media tanam (rhizosphere) terhadap produksi daun stevia dan (ii) menganalisis kelayakan finansial dari kegiatan bisnis restorasi rhizosphere. Data yang diambil untuk menjawab tujuan tujuan tersebut diperoleh dari penelitian lapangan dengan menggunakan metode uji plot bersamaan dengan Complete Randomized Group Design (CRD) yang terdiri dari 15x2 eksekusi dan 3 replikasi. Plot berukuran $2 \mathrm{~m} \times 0.6 \mathrm{~m}(1.2 \mathrm{~m} 2)$. Hasil penelitian menunjukkan bahwa restorasi rhizosphere mampu meningkatkan produksi bunga stevia (dalam bentuk 
kering). Analisis kelayakan usaha menunjukkan bahwa B/C ratio $>1$, NPV $>0$, IRR 20\%, dan BEP unit dan BEP harga terlampaui. Hal ini mengindikasikan bahwa bisnis restorasi ini menguntungkan secara finansial. Namun, bisnis ini sensitif terhadap perubahan manfaat dan biaya. Berdasarkan analisis yang dilakukan, peneliti menyarankan untuk meningkatkan produksi bunga stevia dengan presentase yang lebih besar dari presentase saat ini.

Kata kunci: rizosfir, produksi, kelayakan financial.

\section{INTRODUCTION}

Due to health concerns, global sugar consumption has decreased and is being replaced by low calorie sweeteners such as stevia sugar. Stevia sugar is a glycoside which does not contain calories and can decrease blood sugar therefore suitable for people dealing with obesity and diabetes. Stevia sugar interest has increase due to the rise of obese population and diabetes and society's awareness of health (Pusat Penelitian Bioteknologi dan Bioindustri Indonesia, 2008)

According to Driadsiwi (2012) stevia farming has its advantages and disadvantages which needs to be acknowledged if this plant would be cultivated. The advantages of stevia farming include: (1) stevia farmer may easily receive new technology, (2) the quality and quantity of stevia leaf production is sufficient, (3) cultivation is easy and low risk, (4) stevia leaf demand keeps rising, and (5) production facilities for stevia farming is easy to attain. The disadvantages include: (1) farmers have difficulty acquiring capital, (2) farmers limited managerial capacity, (3) sale prices still depend on agreed price as opposed to established price, (4) decreased output during rainy season, and (5) difficulty to dry stevia leaves during rainy season.

The research locations soil is the Ultisol type, developed from a raised swamp dating back from the Pleistocene age, and continued to develop by leaving sandy clay loam texture, acidic properties and low soil fertility. The root zone as a growing medium is quite shallow, contains a lot of zinc oxide, the lower layer has massive characteristics, soil water is relatively not connected with this root zone.

In order to develop stevia farming there needs to be a restoration of the rhizosphere to increase stevia leaf production. This research aims to (i) analyse the impact of rhizosphere toward stevia leaf production and (ii) analyse financial likelihood rhizosphere restoration. This research was executed in Sugar Group Companies Lampung, a company that is developing stevia farming to produce stevia leaf as a stevia sugar ingredient.

\section{METHODS}

Project can be defined as an entire activity which involves resource utilization 
in order to gain benefit. Project can also be defined as an activity where a certain sum of money is spent in the present time with the hopes of acquiring a return in the future. Restoring growth medium (rhizosphere) is considered a project as it involves spending a certain amount of capital and manpower to restore rhizosphere for stevia planting to produce stevia leaves in the future.

\section{Experiment Design}

Field research in the form of plot experiment is executed by utilizing Complete Randomized Factorial Design (CRD) which is comprised of 3 factors with 3 replications on each combination. Plot size used is $2 \mathrm{~m} \times 0,6 \mathrm{~m}(1,2 \mathrm{~m} 2)$. Factor I is 3 dosages of manure, which are: (1) $0 \%$ manure (A), (2) 2\% manure (B), and (3) $4 \%$ manure (C). Factor II is 5 types of soil, which are (1) mixture of KarangAnyar soil with GPM soil ratio 1:1 (K), (2) mixture of Mulo soil with GPM soil ration 1:1 (M), (3) mixture of Paliyan soil with GPM soil ratio 1:1 (P), (4) mixture of Tawangmangu soil with GPM soil ratio 1:1 (T), and (5) Pure GPM soil (G). Factor III are 10 plants with the amount of seed/planting holes at every plot divided into two, which are: (1) 1 seed/ planting hole, and (2) 3 seeds/planting hole.

Preliminary soil analysis and manure is executed at the beginning of the experiment, parameters observed are harvest results after the plant is 2 months old which will be presented as the weight of dried stevia leaves in ton/ha.

\section{Data Analysis}

The analysis of growth medium (rhizosphere) restoration toward dry stevia leaf production in at SGC Lampung is executed with ANOVA with 5\% significant difference.

\section{Mathematics Model}

$$
\mathrm{Hijk}=\pi+\mathrm{Pj}+\mathrm{Pk}+(\mathrm{Pj} \mathrm{x} \mathrm{Pk})+\text { eijk }
$$

Hijk : Result of treatment to-j and treatment to-k on repetition no-i

$\pi \quad$ : General middle value

$\mathrm{Pj} \quad$ : Treatment factor effect to- $\mathrm{j}$

$\mathrm{Pk} \quad$ : Treatment factor effect to-k

Pj x Pk : Treatment to-j and treatment to-k interaction

Table 1. Experiment Design

\begin{tabular}{llccccc}
\hline \multirow{2}{*}{ Treatment } & \multirow{2}{*}{ Seed/hole } & \multicolumn{5}{c}{ Rhizosphere } \\
\cline { 3 - 6 } & & K. & M. & P. & T. & G. \\
\hline A. 0\% manure & \multirow{2}{*}{ P1.1 seed } & KAP1 & MAP1 & PAP1 & TAP1 & GAP1 \\
B. 2\% manure & & KBP1 & MBP1 & PBP1 & TBP1 & GBP1 \\
C. 4\% manure & & KCP1 & MCP1 & PCP1 & TCP1 & GCP1 \\
D. 0\% manure & \multirow{2}{*}{ P2.3 seed } & KAP3 & MAP3 & PAP3 & TAP3 & GAP3 \\
E. 2\% manure & & KBP3 & MBP3 & PBP3 & TBP3 & GBP3 \\
F. 4\% manure & & KAP3 & MAP3 & PAP3 & TAP3 & GAP3 \\
\hline
\end{tabular}


Eijk : Error due to treatment to-j and treatment to-k on repetition no-i

I $\quad: 1,2, \ldots, \mathrm{u}(\mathrm{u}=$ replication $)$

J $\quad: 1,2, \ldots, p$ toward $1(\mathrm{p}=$ treatment toward 1)

$\mathrm{K}: 1,2, \ldots \ldots \mathrm{p}$ toward $2(\mathrm{p}=$ treatment toward 2)

To analyse financial likelihood of rhizosphere restoration (growth medium) for stevia cultivation at Sugar Group Companies Lampung, NPV, BC ratio, and IRR analysis were executed as follows.

\section{Net Present Value (NPV)}

Rhizosphere restoration is beneficial if NPV $>0$, below is the NPV formula.

$$
N P V=\sum_{t=0}^{T}\left(B_{t}-C_{t}\right)(1+r)^{t}
$$

Source: Gittinger, 1979)

\section{Benefit Cost Ratio (BCR)}

Rizosphere restoration is beneficial if $\mathrm{BCR}>1$, below is the BCR formula.

$$
B C R=\left[\sum_{t=0}^{T} B_{t}(1+r)^{t}\right] /\left[\sum_{t=0}^{T} C_{t}(1+r)^{t}\right]
$$

Source: Gittinger, 1979)

\section{Inter Rate of Return (IRR)}

Rizosphere restoration is beneficial if IRR >interest rate. IRR is the discount rate where NPV = zero, bellow is the IRR formula.

$$
\sum_{t=0}^{T}\left(B_{t}-C_{t}\right)(1+I R R)^{t}=0
$$

Source: Gittinger, 1979)

$B_{t}=$ benefit on year no-t, stevia

production value in the form of dried leaf

$C_{t}=$ costs on year no-t, including (i) cost of pre-producing plants (TBM): field preparation, sowing, maintenance, (ii) cost of producing plants (TM): maintenance, harvest, drying.

$r=$ discount rate

$T=$ time

\section{Break Even Point}

$$
B E P-U n i t=\frac{F C}{P-V C}
$$

Source: Gittinger, 1979)

$\mathrm{BEP}=$ Break Even Point Unit

$\mathrm{FC}=$ Fixed Cost Total

$\mathrm{VC}=$ Variable Cost per Unit

$\mathrm{P} \quad=$ Price per Unit

$\mathrm{BEP}-$ Price $=\frac{\mathrm{TC}}{\mathrm{Q}}=\frac{\mathrm{TFC}+\mathrm{TVC}}{\mathrm{Q}}$

Source: Gittinger, 1979)

BEP-Price $=$ Price Break Even Point

TFC $=$ Total Fixed Cost Total

TVC $=$ Total Variable Cost Total

$\mathrm{Q}=$ Production 


$$
\text { BEP-Rupiah }=\frac{F C}{1-\frac{V C}{S}}
$$

Source: Gittinger, 1979)

$$
\begin{array}{ll}
\text { BEP-Rupiah } & =\text { Break Even Point Rupiah } \\
\text { FC } & =\text { Fixed Cost Total } \\
\text { VC } & =\text { Variable Cost Total } \\
\text { S } & =\text { Sale Value }
\end{array}
$$

There are 2 types of project analysis which are financial analysis and economic analysis. Financial analysis focuses on the results from the capital invested into the project. Financial analysis is important to review incentives for stakeholders whom support the project. Whereas, economic analysis is focused on total result or productivity or benefit for citizens or economy as a whole (Gittinger, 1979 and Squire and Van der Tak, 1975). This research analyses the project from the view point of the company or financial likelihood analysis.

Research involving horticulture farming financial likelihood analysis show many horticulture farming which is financially likely to develop. Such as (i) ginger farm in Tajinan Village, Tajian District, Malang Regency (Sipriani, 2001), (ii) konyal passion fruit in Arosuka Village, GunungTalang District, Solok Regency, West Sumatera Province (Karmila, 2013), (iii) banana farm in Pesawaran Regency (Marga, 2016), dan (iv) local durian fruit nursery farming (Febriati, HidayahandAstuti. 2017).

Results from the research done by Yuniarsanty (2017) shows average cost of stevia farming is $\mathrm{Rp} 8.208 .302 / \mathrm{farm} /$ year with a turnover of $\mathrm{Rp} 15.082 .800 / \mathrm{farm} /$ year and revenue of Rp 6.874.497/farm/ year. The average revenue of stevia and non-stevia farms are Rp 43.071.075/year or stevia farming contributes to $15,96 \%$ of overall farming revenue. The factors that impact stevia farming revenue are field area and pesticide price. On the contrary, seed prices, manure price, labour costs, and land ownership does not affect revenue.

Yang et. al. (2013) states that a combination of inorganic and organic fertilizer can possibly increase stevia plant production compared to only administering inorganic or organic fertilizer, however organic fertilizer should be higher than inorganic fertilizer. Wibowo (2013) also states that (i) administering nitrogen fertilizer can increase biomass production in stevia plants, (ii) nitrogen properties increase assimilation process which results can be used for cell filling, (iii) carbon properties within plants influence sugar development within the plant itself through photosynthesis, (iv) administering $4 \mathrm{mg}$ dosages of nitrogen fertilizer per plant gives optimum results in terms of number of leaves and dry leaf weight, and (v) there is not yet a certain optimum nitrogen fertilizer dosage for growth and stevia plant results. 


\section{RESULTS AND DISCUSSION}

\section{Characterization of Used Materials}

The characterization of the used material for rhizosfer restoration that able to increase the natural soil from GPM is shown at the Table 2.

Blotong and manure were not wholly organic material, it was mixed with residual soil from the field for blotong, and including some of surface soil for manure. Nonetheless both of these organic fertilizers were capable of contributing slow releasing nutrients such as $\mathrm{N}, \mathrm{P}, \mathrm{K}, \mathrm{Ca}$, and $\mathrm{Mg}$ since the $\mathrm{C} / \mathrm{N}$ ratios still above 20 . The source of raw materials of both organic manures is residual arable plant, consists of 16 nutrients, so this organic fertilizer also contains meso and micro nutrients such as $\mathrm{Cl}, \mathrm{SO}_{4}, \mathrm{Mn}, \mathrm{Cu}, \mathrm{Zn}, \mathrm{B}$, but these nutrients was not been analysed.

Soil as material for amelioration was taken from Central Java and Special Region of Yogyakarta. According to USDA Soil Taxonomy (2010) the Vertisol taken from Mulo - GunungKidul District, Alfisol from Paliyan - GunungKidul, Andisol from Tawangmangu - Karanganyar, and Alfisol from Karanganyat. The chemistry characteristics compared to local sources (GPM), organic contents were generally medium in quality, $\mathrm{P}$ contents were low level, and $\mathrm{K}, \mathrm{Ca}$, and $\mathrm{Mg}$ availabilities were generally medium to high level. In GPM soils the high levels of $\mathrm{P}$ and $\mathrm{Ca}$ were caused by intensive fertilizing which was executed upon which was especially taken from stevia cultivation.

\section{Harvest Results}

The more organic fertilizer is applied, the result is heavier dried stevia, the highest value was at $4 \%$ organic fertilizer applied. Same was also for amount of seed, 3 seeds/ planting hole produced heavier amounts of dried stevia leaves compared to seeds which were planted 1 seed/planting hole. The best treatment in increasing dry weight stevia plant was Paliyan soil + GPM soil type (Factor $\mathrm{P}$ ) with $4 \%$ manure dosage (Factor C) and seeds as much as 3 plants (Factor P3), followed by Paliyan soil + GPM soil type (Factor P) and 2\% manure

Table 2. Organic Fertilizer and Soil Characterization

\begin{tabular}{|c|c|c|c|c|c|c|c|c|c|}
\hline \multirow{2}{*}{ Material } & \multirow{2}{*}{$\frac{\mathrm{pH}}{\mathrm{H}_{2} \mathrm{O}}$} & \multirow{2}{*}{$\frac{\% \mathrm{C}-\mathrm{Org} .}{\mathrm{KCl}}$} & \multirow{2}{*}{$\begin{array}{c}\% \\
\text { total } \mathrm{N}\end{array}$} & \multirow{2}{*}{$\mathrm{C} / \mathrm{N}$} & \multirow{2}{*}{$\begin{array}{c}\text { Av. } \\
(\mathrm{ppm})\end{array}$} & \multicolumn{4}{|c|}{ Available (me \%) } \\
\hline & & & & & & $\mathrm{P}$ & $\mathrm{K}$ & $\mathrm{Ca}$ & $\mathrm{Mg}$ \\
\hline Blotong & 7.19 & 7.09 & 37.63 & 1.29 & 29.17 & 275.23 & 4.58 & 29.82 & 4.35 \\
\hline Manure & 7.28 & 7.10 & 30.0 & 1.14 & & 329.77 & 9.43 & 19.56 & 4.10 \\
\hline Mulo Soil & 6.17 & 5.81 & 2.65 & 0.18 & 14.72 & 8.70 & 0.40 & 7.91 & 0.86 \\
\hline Paliyan Soil & 7.10 & 6.88 & 1.55 & 0.11 & 14.10 & 9.30 & 0.91 & 9.17 & 0.73 \\
\hline Tawangmangu Soil & 6.73 & 6.44 & 4.12 & 0.27 & 15.26 & 3.30 & 0.41 & 8.88 & 0.75 \\
\hline Karanganyar Soil & 5.49 & 5.25 & 1.46 & 0.09 & 16.22 & 7.06 & 0.42 & 3.72 & 0.77 \\
\hline GPM Soil & 4.64 & 4.51 & 0.99 & 0.08 & 11.87 & 55.87 & 0.14 & 2.03 & 0.22 \\
\hline
\end{tabular}

Source: Laboratory analyses data 
dosage (Factor B) and seed as much as 3

plants (Factor P3)

GPM sosil (local) actually gives a considerably high result, even higher than Tanah Mulo and Karangayar, even though not statistically different. The lowest treatment was Tawangmangu soil + GPM soil type (Factor T) with a $0 \%$ manure (Factor A) dosage and seed as much as 1 plant. It was suspected that there was a change in soil characteristic originating from Tawangmangu (1.100 above sea level which in its natural condition always humid and low temperature, when placed on lowlands and hotter temperature which changed its humid characteristics. Organic fields will easily absorb water in humid conditions (hydrophilic), however at high temperature its characteristics deviate and repel water (hydrophobic). Another thing is that there is no real interaction between the three treatment factors stated.

\section{Economical Value Calculation}

Dry stevia leaf production experiment can be referenced on table 3.3. MGS 3 varieties produced the lowest dry stevia leaf production at 0,58 ton per ha per year, and $\mathrm{DH} 3$ varieties produced the highest at 1,42 ton per ha per year. Overall or average production experiment produced 1,12 ton dry stevia leaf per ha per year. Experiment suggests that dry stevia leaf production is not different between the first year and the following years up to 10 years. Based on production level stevia price of IDR 120.000 per $\mathrm{kg}$, production value of dry stevia leaf ranges between IDR 69,6 million

Table 3. Dry Weigh of 2 months old Stevia Plant Harvest (ton/ha)

\begin{tabular}{|c|c|c|c|c|c|c|c|}
\hline \multirow{2}{*}{ Treatment } & SOIL & \multicolumn{6}{|c|}{ Average } \\
\hline & $\mathrm{K}$ & M & $\mathrm{P}$ & $\mathrm{T}$ & G & & \\
\hline A & & $0.54^{\text {efghi }}$ & $0.51^{\text {fghi }}$ & $0.65^{\text {abcdefghi }}$ & $0.37^{\mathrm{i}}$ & $0.64^{\text {abcdefghi }}$ & 0.54 \\
\hline B & & $0.46^{\text {hi }}$ & $0.61^{\text {abcdefghi }}$ & $0.59^{\text {abcdefghi }}$ & $0.59^{\text {abcdefghi }}$ & $0.49^{\text {ghi }}$ & 0.55 \\
\hline $\mathrm{C}$ & P1 & $0.64^{\text {abcdefghi }}$ & $0.64^{\text {abcdefghi }}$ & $0.73^{\text {abcdefg }}$ & $0.36^{\mathrm{i}}$ & $0.63^{\text {abcdefghi }}$ & 0.60 \\
\hline A & & $0.82^{\text {abcde }}$ & $0.78^{\text {abcdefg }}$ & $0.85^{\mathrm{abcd}}$ & $0.56^{\text {abcdefghi }}$ & $0.99^{\mathrm{ab}}$ & 0.80 \\
\hline B & & $0.80^{\text {abcdef }}$ & $0.57^{\text {abcdefghi }}$ & $0.82^{\text {abcde }}$ & $0.64^{\text {abcdefghi }}$ & $0.85^{\mathrm{abcd}}$ & 0.74 \\
\hline $\mathrm{C}$ & P3 & $0.97^{\mathrm{abc}}$ & $1.00^{\mathrm{ab}}$ & $1.06^{\mathrm{a}}$ & $0.69^{\text {abcdefgh }}$ & $0.95^{\mathrm{abc}}$ & 0.93 \\
\hline Average JT & $0.70^{\mathrm{b}}$ & $0.69^{b}$ & $0.78^{\mathrm{b}}$ & $0.54^{\mathrm{a}}$ & $0.76^{\mathrm{b}}$ & & $(-)$ \\
\hline Average P & $\mathrm{P} 1=0.56^{\mathrm{b}}$ & $\mathrm{P} 3=0.82^{\mathrm{a}}$ & & & & & \\
\hline $\begin{array}{l}\text { Average ABC } \\
\mathrm{KK}(\%)=9.21\end{array}$ & $\mathrm{~A}=0.67^{\mathrm{a}}$ & $\mathrm{B}=0,64^{\mathrm{a}}$ & $\mathrm{C}=0,77^{\mathrm{b}}$ & & & & \\
\hline
\end{tabular}

Note:

P1 = Seed Amount 1 plant; $\mathrm{P} 3=$ Seed Amount 3 plant;

$\mathrm{A}=0 \%$ manure; $\mathrm{B}=2 \%$ manure; $\mathrm{C}=3 \%$ manure;

$\mathrm{K}=$ KarangAnyar soil + GPM soil; $\mathrm{M}=$ Mulo soil + GPM soil;

$\mathrm{P}=$ Paliyan soil + GPM soil; $\mathrm{T}$ Tawangmangu soil + GPM soil;

$\mathrm{G}=$ Pure GPM soil 
Table 4. Stevia Leaf Production and Production Value

\begin{tabular}{|c|c|c|c|c|}
\hline \multirow[b]{2}{*}{ Varieties } & Production (ton/ha/year) & \multicolumn{3}{|c|}{ Production Value (Million IDR/ha/year) } \\
\hline & Year-1 & Year-2 etc & Year-1 & Year- 2 etc \\
\hline DH 1 & 0.96 & 0.96 & 115.2 & 115.2 \\
\hline DH 1-2 & 1.34 & 1.29 & 160.8 & 154.8 \\
\hline MG 2 & 1.26 & 0.87 & 151.2 & 104.4 \\
\hline DH 3 & 1.42 & 1.08 & 158.4 & 120.9 \\
\hline MGS 3 & 0.58 & 0.97 & 69.6 & 83.5 \\
\hline Average & 1.12 & 1.04 & 134.4 & 120.5 \\
\hline
\end{tabular}

Table 5. Material and Labour Costs in Rhizosphere Restoration Effort

\begin{tabular}{|c|c|c|c|}
\hline No & Cost Components & Year -1 & Year-2etc \\
\hline A & Investment Costs (Million IDR/ha/year) & & \\
\hline A.1. & Material (Million IDR/ha/year) & & \\
\hline A.1.1 & Soil & 200 & \\
\hline A.1.2. & Manure 2\% & 15.12 & 15.12 \\
\hline A.1.3 & Manure $4 \%$ & 30.24 & 30.24 \\
\hline A.1.4. & DAP (substitute for TSP and ZA) & 2.25 & 2.25 \\
\hline A.1.5. & Dolomite/Lime & 2.95 & 2.95 \\
\hline \multirow[t]{2}{*}{ A.1.6. } & Zinc Sulphate & 0.01 & 0.01 \\
\hline & Total Material & 250.57 & 50.57 \\
\hline A.2. & Labour (Million Rp/ha/year) & & \\
\hline A.2.1. & Fungicide Spray & 0.41 & 0.41 \\
\hline A.2.2. & Weeding & 2.08 & 2.08 \\
\hline A.2.3. & Watering & 2.08 & 2.08 \\
\hline A.2.4. & Bud Cutting & 4.16 & 4.16 \\
\hline A.2.5. & Flower Cutting & 4.16 & 4.16 \\
\hline \multirow{3}{*}{ A.2.6. } & Sowing & 2.91 & 2.91 \\
\hline & Total labour & 15.8 & 15.8 \\
\hline & Total material + labour & 266.37 & 66.37 \\
\hline B. & Operational Costs (Million Rp/ha/year) & & \\
\hline B.1. & Material (Million Rp/ha/year) & & \\
\hline B.1.1. & Zinc Sulphate & 0.06 & 0.06 \\
\hline B.1.2. & Potasium Nitrate & 0.06 & 0.06 \\
\hline B.1.3. & PotasiumSuffat & 0.009 & 0.009 \\
\hline B.1.4 & Urea & 0.085 & 0.085 \\
\hline B.1.5 & Agrifos & 0.245 & 0.245 \\
\hline \multirow[t]{2}{*}{ B.1.6. } & Daconil & 0.66 & 0.66 \\
\hline & Total material & 1.119 & 1.119 \\
\hline B.2. & Labour (Million Rp/ha/year) & & \\
\hline B.2.1. & Harverst Labour & 10.41 & 10.41 \\
\hline B.2.2. & Drying Labour & 10.41 & 10.41 \\
\hline \multirow[t]{3}{*}{ B.2.3. } & Storing Labour & $\mathrm{Na}$ & $\mathrm{Na}$ \\
\hline & Total labour & 20.82 & 20.82 \\
\hline & Total material + labour & 21.939 & 21.939 \\
\hline \multirow[t]{4}{*}{$\mathrm{C}$} & Total Costs (Million IDR/ha/year) & & \\
\hline & Investment & 266.37 & 66.37 \\
\hline & Operational & 21.939 & 21.939 \\
\hline & Total & 288.309 & 88.309 \\
\hline
\end{tabular}


up to IDR 160,80 million per ha per year with an average of $\mathrm{Rp} 134,40$ million per ha per year.

Investment in rhizosphere restoration efforts include soil supply, manure, DAP, dolomite, and zinc sulphate (Table 5). Aside from that there are also labour supply for fungicide spraying, weeding, watering, bud cutting, flower cutting, and sowing. Investment costs for material supply amounts to IDR 250,57 million per ha per year, mostly allocated for land supply. Investment on labour amounts to IDR 15,8 million per ha per year. Rhizosphere restoration effort costs include material supply costs of zinc sulphate, potassium nitrate, potassium sulphate, urea, agrifos, and deconil. Aside from that also labour for harvesting, drying, and storing. Overall investment costs of rhizosphere restoration amount to IDR 266,37 million per hectare and operational costs amounts to IDR 21,939 million per ha per year.

Table 6 shows that rhizosphere restoration efforts are financially beneficial, demonstrated by $\mathrm{B} / \mathrm{C}$ numbers higher than 1 , NPV number higher than zero, and IRR numbers that are quite high. $\mathrm{B} / \mathrm{C}$ is found at 1,08 for $10 \%$ interest, 1,10 for $7,5 \%$ interest, and 1,12 for $5 \%$ interest. NPV is found at 60,66 for $10 \%$ interest, 84,28 for $7,5 \%$ interest, and 112,99 for $5 \%$ interest. IRR is found at $20 \%$, which means that investment profit of rhizosphere restoration is quite high at $20 \%$.

Nevertheless, rhizosphere investment is prone toward benefit and cost changes (Table 7). A 5\% cost increase along with

Table 6. B/C ratio, NPV, and IRR Rhizosphere Restoration Efforts on Initial Benefit and Cost Value

\begin{tabular}{lrrr}
\hline \multicolumn{1}{c}{ Year } & \multicolumn{1}{c}{ Benefit } & \multicolumn{1}{r}{ Cost } \\
\hline Yr-1 & 134.4 & 288.309 & -153.909 \\
Yr-2 & 120.48 & 88.309 & 32.171 \\
Yr-3 & 134.4 & 88.309 & 46.091 \\
Yr-4 & 120.48 & 88.309 & 32.171 \\
Yr-5 & 134.4 & 88.309 & 46.091 \\
Yr-6 & 120.48 & 88.309 & 32.171 \\
Yr-7 & 134.4 & 88.309 & 46.091 \\
Yr-8 & 120.48 & 88.309 & 32.171 \\
Yr-9 & 134.4 & 88.309 & 46.091 \\
Yr-10 & 120.48 & 88.309 & 32.171 \\
B/C 10\% & IDR785.10 & IDR724.44 & 1.083736 \\
B/C 7.5\% & IDR876.49 & IDR792.21 & 1.106385 \\
B/C 5\% & IDR 939.46 & IDR838.64 & 1.120219 \\
NPV 10\% & & & $\$ 60.66$ \\
NPV7.5\% & & & $\$ 84.28$ \\
NPV 5\% & & & 112.9938 \\
IRR & & & $20 \%$ \\
\hline
\end{tabular}


Table 7. B/C ratio, NPV, and IRR Rhizosphere Restoration Effort if Benefit Value Falls 5\% and Cost Value Rises 5\%

\begin{tabular}{|c|c|c|c|}
\hline Year & B & $\mathrm{C}$ & B-C \\
\hline Yr-1 & 127.68 & 302.7245 & -175.044 \\
\hline Yr -2 & 114.456 & 92.72445 & 21.73155 \\
\hline Yr -3 & 127.68 & 92.72445 & 34.95555 \\
\hline Yr -4 & 114.456 & 92.72445 & 21.73155 \\
\hline Yr -5 & 127.68 & 92.72445 & 34.95555 \\
\hline Yr -6 & 114.456 & 92.72445 & 21.73155 \\
\hline Yr -7 & 127.68 & 92.72445 & 34.95555 \\
\hline Yr -8 & 114.456 & 92.72445 & 21.73155 \\
\hline Yr -9 & 127.68 & 92.72445 & 34.95555 \\
\hline Yr -10 & 114.456 & 92.72445 & 21.73155 \\
\hline B/C 10\% & $\$ 745.85$ & $\$ 760.66$ & 1.019864 \\
\hline B/C $7.5 \%$ & $\$ 832.66$ & $\$ 831.82$ & 0.998986 \\
\hline B/C 5\% & $\$ 936.10$ & $\$ 915.99$ & 0.978521 \\
\hline NPV 10\% & & & $(\$ 14.82)$ \\
\hline NPV7.5\% & & & $\$ 0.84$ \\
\hline NPV 5\% & & & $\$ 20.11$ \\
\hline IRR & & & $8 \%$ \\
\hline
\end{tabular}

Table 8. Unit BEP and Price BEP Stevia Plant Rhizosphere Restoration Effort

\begin{tabular}{cc}
\hline Formula & Calculation \\
\hline BEP-Unit $=\frac{F C}{P-V C}(\mathrm{~kg})$ & $\frac{26.63}{0.12-0.019637}=265.3368$ \\
BEP - Price $=\frac{T C}{Q}=\frac{T F C=T V C}{Q}\left(\right.$ million $\left.\frac{R p}{k g}\right)$ & $\frac{26.63+21.93}{1120}=0.043357$ \\
\hline
\end{tabular}

a $5 \%$ benefit drop causes this investment to be unprofitable. His change affects $\mathrm{B} / \mathrm{C}$ to become less than one unless $\mathrm{B} / \mathrm{C}$ is on $10 \%$ interest. Same applies for NPV which becomes negative for a $10 \%$ interest and IRR drops to only $8 \%$. This result shows that rhizosphere restoration efforts have to be able to increase stevia leaf production even greater in order for it to be not prone to cost and benefit changes.
BEP analysis results (Table 8) shows that BEP unit was achieved at 265,33 stevia production and price BEP of stevia price was achieved at IDR 0,043357 million $/ \mathrm{kg}$. Unit BEP and price BEP was exceeded at $1120 \mathrm{~kg} / \mathrm{ha}$ per year for production and IDR $120.000 / \mathrm{kg}$ for price. Therefore, rhizosphere restoration efforts are profitable looking from the production and price point of view. 


\section{CONCLUSION AND SUGGESTION}

\section{Conclusion}

The effort to restore rhizosphere can increase dry stevia leaf production. Financial likelihood analysis of rhizosphere restoration shows that $\mathrm{B} / \mathrm{C}$ ratio is greater than one, $\mathrm{NPV}$ is greater than zero, IRR is quite large at 20\%, Unit BEP and Price BEP was exceeded, showing that rhizosphere restoration is financially beneficial. However, rhizosphere restoration efforts are still sensitive toward benefit and cost changes.

\section{Suggestions}

Taking into account that financial likelihood of rhizosphere restoration efforts are still sensitive toward benefit and cost changes, there needs to be an effort to an even higher production increase of dried stevia leaves.

\section{REFERENCES}

Driadsiwi, Aninda Putri. 2012. Analisis Usahatani dan Prioritas Strategi Pengembangan Daun Stevia di Desa Kalisoro Kecamatan Tawangmangu Kabupaten Karanganyar. Skripsi Fakultas Pertanian Universitas Sebelas Maret Surakarta.

Febriati, Meri; Abdul Kholik Hidayah; dan Puji Astuti. 2017. Analisis Finasial Usahatani Pembibitan Buah Durian Lokal (Duriozibethinus L.) Pada Tingkat Kelompok Tani Kecamatan
Barong Tongkok Kabupaten Kutai Barat. Jurnal AGRIFOR Volume

XVI, Nomor 1, Maret 2017

Gittinger, J. Price. 1979. Economics Analysis of Agricultural Project, Revised Edition. IBRD.

Karmila. 2013. Analisis Kelayakan Finansial Usahatani Markisa Konyal (Passifloralegularis) di Desa Arosuka, Kecamatan Gunung Talang, Kabupaten Solok, Provinsi Sumatera Barat

Marga, Muhammad Fariando. 2016. Analisis Kelayakan Finansial Usahatani Pisang di Kabupaten Pesawaran.Skripsi Fakultas Pertanian Universitas Lampung Bandar Lampung

Pusat Penelitian Bioteknologi dan Bioindustri Indonesia (Indonesian Research Institute for Biotechnology and Bioindustry). 2008. Petunjuk Teknis Budidaya Tanaman Stevia

Squire, Lyn and Herman G. van der Tak. 1975. Economic Analysis of Project. John Hopkins.

USDA, 2010. Key to Soil Taxonomy. Soil Survey Staff.

Wibowo, Fajar Arif Eko,.2013. Peran Pupuk Nitrogen Dalam Pertumbuhan 
dan Hasil Stevia (Stevia Rebaudiana

Bertoni M.), Skripsi Fakultas

Pertanian Universitas GadjahMada.

Yang, J., X. Liu and Y. Shi. 2013. Effect

Different Mixed Fertilizer on Yield, Quality and Economics Benefit in Stevia rebaudiana Bertoni. Adv. Journal Food Science Technology, 5(5): 588-59.
Yuniarsanty, Audina. 2017. Kontribusi Pendapatan Usahatani Stevia Terhadap Total Pendapatan Usahatani dan Faktor-faktor yang Mempengaruhi Pendapatan Usahatani Stevia di Kabupaten Karanganyar. Skripsi Fakultas Pertanian Universitas Sebelas Maret Surakarta. 